\title{
Information Policy and Intellectual Freedom In American Libraries Before and After September 11, 2001: A Global Perspective
}

\author{
Joseph A. CUSTER, Associate Director \\ Lecturer, Faculty of Law Library, University of Kansas, School of Law, USA
}

\begin{abstract}
This paper examines information policy in libraries before and after the tragic destruction of the Twin Towers in New York, New York, on September 11, 2001. It carefully considers libraries' role in the history of intellectual freedom in the United States and on an international scale. It investigates the rocky road that citizens from almost all countries have traveled in attempting to gain open access to information throughout modern history. It appraises some of the advances certain areas of the world have made in regard to intellectual freedom. The paper also investigates some areas of the world that are still confronting various degrees of censorship today. The paper then discusses the effect September 11, 2001 had on intellectual freedom and libraries. It scrutinizes the USA Patriot Act that was quickly passed in the United States in response to the terrorist attack. In addition, the paper explores other legislation from around the world that was enacted in direct reply to September 11, 2001.
\end{abstract}

If the lady from Toledo can be required to disclose what she read yesterday and what she will read tomorrow, fear will take the place of freedom in the libraries, bookstores, and homes of the land. Through the harassment of hearings, investigations, reports, and subpoenas government will hold a club over speech and over the press.

The American Library Association (ALA) has never endorsed one uniform definition of intellectual freedom. While not wanting the restriction of a uniform definition, the ALA has promoted principles intended to foster an advantageous climate for intellectual freedom. Some of these principles are the "right of every individual to seek and receive information without restriction.... Libraries embody the belief that information must not be the exclusive province of a privileged few, but that it be widely and freely available to all, regardless of a person's age, race, background or views." These principles have not always existed in American libraries. This paper will explore some of the changes intellectual freedom has gone through in America and in the world. Judith Krug, Director of the American Library Association's (ALA's) Office of Intellectual Freedom (OIF), states, "Intellectual freedom is based on the First Amendment to the United States Constitution and the library profession's interpretation of the First Amendment.” Krug states the Library Bill of Rights articulates the specific role libraries play in defending intellectual freedom. One of these roles has been the creation of the OIF by the ALA to support and assist librarians facing censorship challenges. Another less formal but very important way libraries defend intellectual freedom is through preserving and making accessible the wide spectrum of political and social thought without fear of government intrusion. Providing wide and diverse collections through a variety of formats also defends intellectual freedom. Even though rooted in the Constitution, intellectual freedom is a rather recent 
phenomenon. This paper will explore its developments over the brief history of the United States and peruse the global aspect of intellectual freedom.

While intellectual freedom may have only been a dream during colonial time in America, books were a reality. Even though there were no significant libraries to speak of in the colonies, some colonists did own books, the Bible being the most prominent according to Matthew Battles, author of Library: A Unquiet History. During the late $18^{\text {th }}$ century and early $19^{\text {th }}$ century, small college and canonical libraries were established, the collections of which were quite small. Individuals such as Benjamin Franklin and others who were interested in debate and selfimprovement formed corporations to buy books and create small subscription libraries. Many of these quasi-public libraries were open to a selective public. An even more selective public, those who were part of the corporation, according to Battles, were allowed to check out the books. "Women were often excluded from social libraries, a policy that made book selection easier. . . When in 1849 some trustees [of the Boston Athenaeum] advocated accepting women as readers and employees, the librarian, Charles Folsom, objected that the policy would embarrass male users. Nor was it desirable that a modest young woman be exposed to 'the corrupter portions of polite literature. A general portion of a general library should be to her a sealed book.'” Clearly this was not a young nation trumpeting intellectual freedom. Looking at this issue with a global perspective, matters have not gotten much better in some areas of the world. For example, in Qater, as of 1996, there were still separate libraries for women scholars on campus.

In the early to mid $19^{\text {th }}$ century two factors led to the establishment of public libraries in America. First, the amount and type of reading materials rapidly increased in a relatively short period of time due to the introduction of the mechanical printing presses to various localities in the United States. Second, as the country became wealthier, those with money started to view libraries as potential beneficiaries of charitable endowment. During this period, the Industrial Revolution drove the creation of Mechanics' Institute libraries in England. These libraries were created with the incentive of educating workers. Canada also patterned similar libraries after Britain's system.

Although subscription libraries are commonly considered the direct precursors to public libraries, the early proponents of public libraries were clearly influenced by the ideals of the community libraries. It was during this time, and even before, when books were first being mass produced that free African Americans were being turned away from the doors of the subscription and public libraries. This injustice, which marinated in its own particular kind of American flavor, can be viewed today as the antithesis to intellectual freedom. It permeated itself throughout the United States up to and through Reconstruction, Jim Crow and Plessy $v$. Ferguson's "separate but equal.” This inequality cannot lay solely at the feet of the early American libraries. Separate subscription libraries were established in Scotland during the eighteenth century. One library for the working class and one for the middle class.

During the early to mid $19^{\text {th }}$ century, African Americans banded together to create their own subscription and public libraries. The Library Company of Philadelphia, for example, was created by African Americans in 1832. It was there and at other similar libraries where African Americans met to exchange ideas and information. Libraries for African Americans became more than an intellectual and social organ. They became political organs where the cause of 
freedom could be discussed (Battle, 2004). In general, nineteenth century society accepted restrictions on acceptable reading material, particularly fiction. In the late 1860s the movement towards moral censorship reached its peak when Comstockery took root in America. Anthony Comstock led the anti-obscenity movement that led to the Comstock Act which affected intellectual freedom over the next sixty years in America. Books banned under the Comstock law included many of the greatest classics: Aristophanes' Lysistrata, Rabelais's Gargantua, Chaucer's Canterbury Tales, Boccaccio's Decameron and even The Arabian Nights. An earlier English crusader who inspired Comstock was Thomas Bowdler. Interestingly, Bowdler was a physician who had a physical declination toward the sick. Due to this occupational hazard he spent most of his life working on prison reform and "bowdlering" literature of its indelicacies. His most famous publication was Family Shakespeare. He extracted all tawdry language from Shakespeare that a gentleman could not read aloud in the company of ladies.

\section{Establishment of the American Library Association and the First Library Bill of Rights}

In 1876, the American Library Association was established. The early leaders were very careful to promote the librarian as the gatekeeper to good reading. In 1879, Melvil Dewey devised the first ALA motto, "The best reading for the largest numbers at the least cost." The phrases "largest numbers" and "the least cost" certainly have intellectual freedom connotations. The "best reading" phrase, however, is very indicative of the role librarians were thought to hold at the time in America: the role of making the moral and intellectual choices as to what was best for people to read. In one of his articles, Dewey stated that as a city takes steps to promote pure water to its residents, a public library must exclude the pernicious and provide the pure and wholesome for society. American libraries got closer to the notion of intellectual freedom during the last decade of the $19^{\text {th }}$ century and the first decade of the $20^{\text {th }}$ century but still had a ways to go when World War I broke out.

American libraries during the years of World War I were confusing censorship with patriotism and were more than willing to display this jumbled patriotism at the expense of intellectual freedom. W. F. Woodward, a Portland (Oregon) Public Library board member in 1919, urged the Portland library board to bar all foreign language papers and periodicals not published "in the American language" (Chadwell, 2002). It was also during this time in history that the Wisconsin Library Commission stated in response to censoring books that "To be neutral now is to be disloyal" (Chadwell, 2002). World War I precipitated new censorship mechanisms in Europe. The London Globe printing plant was seized by British officials. In Bohemia, French books were banned. In Ireland, government officials seized the printing presses and plants of the Nubaner, Kerryman and Liberator newspapers.

The entry of America into the First World War helped establish many of the grounds upon which intellectual freedom battles would be fought in the twentieth century. At the time, the perceived influence of German-friendly books was a major issue during the war. A political as opposed to a moral censorship was a new aspect not previously seen in American society. We can see this political censorship especially with the list of books banned from troop camp libraries that were set up during the war. This list consisted primarily of political tracts, polemics about war, and books about the history and ideology of Germany. The German government 
issued the Official Censorship Book for the German Press in 1917 which listed prohibited subjects. Russia censored all news leaving Russia. As stated by Nikola Lenin:

The capitalists define freedom of the press as the suppression

of the censor and the power for every part to publish newspapers

as they please. In reality that is not freedom of the press but

freedom for the rich, for the bourgeois to deceive the

oppressed and exploited masses of the people. State

monopoly of newspaper advertising is the only solution.

After the First World War, most American libraries continued to advocate the role of gatekeeper well into the late 1920s and 1930s.

A turning point transpired in American libraries in 1933 when Forrest Spaulding, the library director of the Des Moines, Iowa, Public Library, disseminated his "Bill of Rights for the Free Public Library," prior to the 1938 ALA midwinter meeting. This was the first true attempt at intellectual freedom by American librarians. The Des Moines document and the banning of John Steinbeck's Grapes of Wrath by many American libraries in the late 1930s were probably the two most significant events rallying the ALA and ultimately leading to the creation of the first ALA Library Bill of Rights.

The impact of the ALA Library Bill of Rights was unfortunately not great but it did demonstrate the American Library Association's first attempt to foster intellectual freedom. Included in this early document was language concerning the privacy of individual patrons, addressed formally by the American Library Association for the first time.

\section{World War II to McCarthyism}

The 1940s marked World War II for the United States and the world. It was also the first decade that the Federal Bureau of Investigation attempted to obtain private documents from a library in the United States. J. Edgar Hoover, who developed some of his ideas regarding information while he worked in the Library of Congress from 1913 to 1917, asked the Library of Congress to turn over Boris Brasol's papers in 1942. Brasol, a person with pro-fascist leanings, was a former diplomat, noted author and lecturer and had deposited his 46 boxes of manuscripts with the Library of Congress in 1939. It was uncertain as to how Hoover's request would be greeted because Hoover had collaborated with the Head Librarian of Congress, Archibald MacLeish, on several matters, and the two were known to have a working relationship. MacLeish was also known to be one of President Roosevelt's leading anti-Fascists. He had been appointed by Roosevelt to head the quasi-propaganda Office of Facts and Figures before Pearl Harbor. MacLeish's response to Hoover was firm. He noted the importance of privacy and keeping a promise to a noted figure who gifted his papers to the Library of Congress. Hoover reluctantly accepted MacLeish's wishes with quiet civility, a practice that stands in contrast to the confrontations manufactured by Hoover's successors in later library surveillance dealings.

May 10, 1942, was the eighth anniversary of when Wilhelm Humboldt University students transported books from their university library to the square on Unter den Linden and set them ablaze. It was also the day that Pulitzer Prize winning poet and novelist Steven Vincent Benet chose to broadcast a radio play entitled They Burnt the Books. Some of the authors whose 
books had been burnt eight years previous, and had fled to America, were actually performing on the radio broadcast. The broadcast was a hit and clearly the memories of the bibliocaust were still fresh on the minds of Americans. It is worth noting that even in 1933 when the barbarism took place, people across the world broke their usual apathy to the unfolding Nazi terrors. Outside of Germany, newspapers the world over, as far away as China and Japan, expressed their horror.

After World War II, when America was thriving, intellectual freedom in libraries was comparatively weak. The Library Bill of Rights adopted in 1939 was not taken to heart. The focus shifted from fighting the Axis to fighting government and public paranoia about Communism. Under pressure from Congress, President Truman created the Loyalty Order in 1947 making it a condition of employment that federal government workers sign an oath denouncing Communism. The Order, intended to quiet Congress, backfired on Truman and helped heighten the red scare. It was also in 1947 that the House Un-American Activities Committee (HUAC), whose self-proclaimed duty was to purge the country of Communism, was established. In addition, J. Edgar Hoover was hitting the speaking circuits around the country adding fuel to the fire with anti-communist propaganda. In response to this firestorm of anticommunism, organizations like the Daughters of the Revolution and the American Legion were calling for libraries to scrape from its shelves anything thought to be subversive. These actions were not totally out of mainstream opinion at the time. "Opinion polls reveal at least tacit approval of harassment of left-wing groups ... nearly half of those polled would have denied Socialists the right to publish newspapers and wanted to forbid the press the right to criticize the government.” Luckily the Intellectual Freedom Committee (IFC) had two successive leaders during this time, Alice Higgins and David K. Berninghausen, who both believed strongly in intellectual freedom. Alice Higgins wrote in a letter to Berninghausen at this crucial time, "our first piece of work is to educate librarians." She then stated that the freedom of the United States, and even the world depended upon a "Free Culture.” David K. Berninghausen, who succeeded Alice Higgins as IFC chairman, along with ALA President Paul North Rice, proposed that the ALA rewrite the Library Bill of Rights in 1948. After being adopted at the Atlantic City ALA Conference in 1948, the new Bill of Rights was met with rave reviews. The new Library Bill of Rights addressed defending free inquiry and fighting censorship. It also clearly placed "libraries in the position of being aggressive defenders of the right to freedom of research and inquiry." Unlike the first version, the ALA took real action to support this version. In 1948, for example, the ALA spoke out for the first time in a public hearing against censorship when it protested the removal of The Nation from New York City schools for a series of articles the school administration had deemed disrespectful of the Catholic Church.

\section{0s}

During the early 1950s American librarians were in constant fear of the McCarthyite hysteria. In the early 1950s, the ALA began to address the issue of labeling. Of course this had always existed in some form or another with the existence of closed shelves and restricted lists but by this time there was a call to contain communist propaganda by labeling works as subversive so that “...library materials may be restrained in use although not actually withdrawn from the collection.” It was recognized that this posed particular intellectual freedom problems because "once labeling is recommended it will be impossible to restrict it to Communist 
literature alone." The IFC took the position that labeling was misguided because it was not safe for any one librarian to distinguish between "good reading" and "bad reading." Librarians knew the neutral and right way on, ". . . how to build a collection that contained a diversity of views, many of them unpalatable, from which citizens would choose to inform themselves." It was in 1953, in reaction to the labeling, zealots and threats, that the ALA published "The Freedom to Read” manifesto. President Eisenhower also helped give much needed hope for libraries and intellectual freedom in 1953 with a letter written in June supporting libraries and librarians. It stated that the librarian's role was one of preserving "the precious liberties of our nation: freedom of inquiry, freedom of the spoken and written word, freedom of exchange of ideas." Also, speaking to the Dartmouth graduates later in June of 1953, Eisenhower stated, "Don't join the book-burners.... Don't be afraid to go in your library and read every book, as long as any document does not offend [y]our own ideas of decency. That should be the only censorship.” The next summer, televised Senate hearings exposed McCarthy's unethical tactics and his fouryear assault on communism thankfully came to an end for all who favored intellectual freedom.

\section{0s}

Finally in the 1960s, the American Library Association was prepared to add race to its notion of intellectual freedom. In 1961, the ALA amended the Library Bill of Rights to read, "The rights of an individual to the use of a library should not be denied or abridged because of his race, religion, national origins, or political views." In 1962, the ALA adopted the "Statement on Individual Membership, Chapter Status, and Institutional Membership." This statement extended the idea of intellectual freedom to include integration for the first time. In reaction, the states of Louisiana and Mississippi withdrew their ALA member status, joining Georgia and Alabama, which had never been redesignated after being dismissed in the 1950s for their racial activity. The Library Bill of Rights was changed in 1967 to reflect the elimination of age as a discriminating factory in library use with the adoption of Section 5 in 1967, "The rights of an individual to the use of a library should not be denied or abridged because of his age, race, religion, national origin or social or political views."

Intellectual freedom kept evolving in the 1960s. It was also in the 1960s that the ALA wrote its first amicus brief which it filed in the California case prosecuting the long-standing ban on Henry Miller's novel, Tropic of Cancer. Prior to 1967, the Library Bill of Rights stated that, "books or other reading material of sound factual authority should not be proscribed or removed from library shelves because of partisan or doctrinal disapproval." Toni Samek states that this earlier version of the Library Bill of Rights actually gave librarians the intellectual right to exclude library materials under the shield of prejudice. If a librarian deemed a source as nonfactual, the item could be removed from the shelves. The Library Bill of Rights was revised in 1967 to read "no library materials should be proscribed or removed from libraries because of partisan or doctrinal disapproval.” Thus, an additional broadening of the concept of intellectual freedom came into existence.

\section{0s}


In 1971 the ALA issued a resolution against the Vietnam War focusing mostly on the economic impact, emphasizing the "conflict in Southeast Asia has so distorted our national priorities as to reduce substantially the funds appropriated for library services to the American people.” The ALA issued another resolution involving the Vietnam War in 1971 concerning the incarceration of Zoia Horn, the Head of Reference of Betrand Library at Bucknell University. Horn was found guilty of contempt and placed in jail for 20 days when she failed to testify in regard to the meetings and social gatherings that became known as the Harrisburg Eight Conspiracy. FBI informant Boyd Douglass had been recruited from the local penitentiary to work as a work-study student at the Betrand Library, to spy and report on the social activities of Dan and Phil Berrigan. The Berrigans, who worked at the library, had broken into a selective service office and destroyed others' draft records. They were viewed by the FBI as threats to the United States. Horn was subpoenaed to testify on Douglass's sworn testimony and she refused. After some initial recalcitrance, the Intellectual Freedom Committee became an advocate and was able to convince the Executive Board of the ALA that Horn's refusal to testify was a defense of the principles of intellectual freedom. The ALA provided Horn with $\$ 500.00$ for support and issued a resolution, which in part said; "The ALA go(es) on record against the use of the grand jury procedures to intimidate anti-war Vietnam War activities and people seeking justice for minority communities."

\section{The 1980s and the "Library Awareness Program"}

It wasn't much later when another government agency intrusion on libraries and intellectual freedom was brought to light. In 1987 it was discovered that the FBI had been conducting a secret investigation of American science libraries since 1973. A librarian at Columbia University overheard two FBI agents asking a library staff member about the reading habits of certain patrons with foreign sounding names or accents. The agents did not have search warrants or subpoenas. The librarian who overheard the questioning reported the incident to University Librarian, Paula Kaufman. Kaufman instructed the FBI agents that if any records were to be garnered by the agents, they would need a court order to comply. The New York Times broke the story in September, 1987. The program was coined by librarians as the Library Awareness Program. In 1988, Congressional hearings ensued which disclosed the FBI's tactics of obtaining information on the reading habits of patrons tied to the Soviet Bloc and also how the FBI was investigating students and even lowly-paid librarians who they thought may be targeted by the Soviets as future spies for the KGB. The subcommittee was highly critical of the FBI's apparent failure to provide its agents with guidelines on how to deal with libraries. FBI Director William S. Sessions, in response to the growing criticism, wrote a letter on September 14, 1988, to Representative Don Edwards of California, the Committee Chair of the Subcommittee on Civil and Constitutional Rights of the House Judiciary Committee and former FBI agent. Sessions suggested the FBI would scale back its efforts. The letter was not very appeasing. Part of it stated, "when deemed necessary, the FBI will continue to contact certain scientific and technical libraries (including university and public libraries) in the New York City area concerning hostile intelligence service activities in libraries." This letter was written after James Geer, Assistant Director to the FBI, sought to portray evidence and criticism that had been offered by librarians as an over-reaction. Geer stated that Soviets were barred access to materials from the National Technical Information Service (NTIS) by executive order. NTIS materials, however, are unclassified materials accessible to anyone. At the hearings, the chair of the ALA 
Intellectual Freedom Committee, C. James Schmidt, asked Geer, "Jim, is there an Executive Order that prohibits access to the NTIS reports by Russian nationals?” Geer answered,” I wish I had brought a copy with me .... I can't remember exactly how it's worded .... but it may say 'representatives of the Soviet Union' .... I can't speak to the wording, but I certainly can speak to the intent. The intent is to deny them access to it."

The "executive order" espoused by Geer and stated in almost all FBI memoranda on the subject did not even mention the NTIS. For more on this and how the program finally came to an end in the late 1980s, please refer to chapter one of Herbert N. Foerstel's book, Refuge of a Scoundrel. One other chilling aspect of the Library Awareness Program was finding out later that the FBI had conducted hundreds of investigations on Americans, including librarians, who had criticized the program. There are now laws in forty-eight states and the District of Columbia which make it illegal for libraries to release patron information to anyone without a court order.

\section{Examples of Global Censorship During the 1950s through the 1980s: Europe}

This part of the paper will not discuss several democratic societies that have taken significant legislative action to give their citizens access to information. Such counties, besides the United States, including Canada, which has passed the "Access to Information Act” in 1982 and Australia and New Zealand respectively, which passed similar legislation in 1982 and 1983. This group of countries also includes India, which provides in Article 19 of the Preamble of the Constitution of India, adopted in 1950, the right to "freedom of speech and expression" as a fundamental right. Europe has emerged gradually from its sensitized state following World War II. In Germany, treatment of right-wing extremity has been censored. German public libraries have not allowed access to Hitler's Mien Kampf or other neo-nazi publications. Czechoslovakia has had what can be termed a colorful approach to censorship during this period (the color being red). A high standing Czech librarian, Rudolf Malek, reported with gratification how Communist Czechoslovakia had removed improper books from the shelves of its libraries and replaced them with appropriate socialist books. France authorities have been involved in several acts of censorship during this period. Arguably the most notorious was in October of 1986 when the Paris Council drew up a children's literature booklist. Librarians were directed to acquire only from the list. This led to the librarian, author and publisher formed collective called Renvoyons la censure (Reject censorship) in 1987. The crumbling of the Soviet empire took place in the late 1980s. Before this however, Glasnost and the openness of the Gorbachev era had lightened the constraints on freedom of opinion and expression. Nevertheless, libraries in Russia were still not allowed to shelve books by authors regarded as anti-Soviet, such as Solzhenitsyn or Orwell. The country of Ireland raised eyebrows amongst its neighbors in Europe in the 1980s when the long forgotten Censorship of Publications Board, established in the 1920s, flexed its atrophied muscles to censor The Joy of Sex and The Erotic Art of India. On December 18, 1986, Turkish authorities pulped 39 tons of books, newspapers and periodicals thought to contain propaganda related to Armenians or Kurds. Some of the sources of "separatist propaganda" included the National Geographic Atlas of the World, The Penguin Map of the World and the Turkish edition of the Encyclopedia Britannica. A long tradition of paternal secrecy has made it very challenging for the committed UK Library Association. In 1988, the association joined the campaign against secrecy once again when records released for the first time under the "Official Secrets Act" revealed that a nuclear accident had occurred at the 
Windscale nuclear plant thirty years previous, in 1957. It had a release of radioactivity level 600 times the disaster at Three Mile Island in America. Only the radioactivity level at Chernobyl has been more devastating. On a positive note, one of the principal demands of the striking solidarity workers in Poland in 1980 was the reduction of censorship. The efforts of the workers led to the creation of the much less obtrusive, "Act on the Control of Publications and Performances” in 1981.

\section{Examples of Global Censorship From the 1950s Through the 1980s: Asia}

In Asia, the form of severe censorship by killing authors in certain countries has continued well into the 1980s. The Taiwanese government admitted in 1985 that it had been an accomplice in the murder of Chinese-American author Henry Liu. In the 1970s South Korea sentenced poet Kim Chi-ha to death. In Indonesia, noted author Pramoedya Ananta Toer was imprisoned in 1965 and was kept incarcerated for several decades. In Singapore, the "Undesirable Publications Act" was passed in 1967. The act banned much material of a sexual nature, such as The Joy of Sex. It has also been used to ban several books containing excessive violence and drug abuse. In a victory over censorship, China lifted its 10 year ban on works of Shakespeare and works of various Russian and German authors in the 1970s.

\section{Examples of Global Censorship From the 1950s Through the 1980s: Africa}

In Africa, certain countries have been very intolerant of authors who have expressed dissident views of the ruling government. In the Peoples Republic of Congo, Emmanuel Boundzcki Dongola had his book of short stories called Jazze et vin de Palme censored for satirizing Marxism and leaders of the ruling government. In Kenya, periodicals and books that criticized the ruling government were routinely banned. In South Africa, writer David Webster was assassinated by an organization that was associated with the apartheid authorities. Revolutionary regimes in Uganda, Zaire and Ethiopia have abducted and murdered writers. Writers and journalists in Morocco have been incarcerated for their writings. Two better known examples are poet Idrissi Kaitouni, sentenced to fifteen years in 1982; and Abraham Serfaty, considered by authorities to be a radical writer for the magazine Souffles. Serfaty received a life sentence in 1974. In 1978, Egyptian poet Ahmed Fouad Negm was sentenced to one year hard labor for writing a poem considered "humiliating" to the Egyptian head of state.

\section{Examples of Global Censorship From the 1950s Through the 1980s: Americas}

Since this paper is centered on the United States and its practices of censorship, this part of the paper will focus on the other countries comprising South, Central, and North America. In Argentina, during the period of military government control of 1976 to 1983, over one hundred journalists and writers "disappeared." Chile was a model of free discourse in South America until 1973. In September 11 of that year, a military coup led by General Augusto Pinochet Ugarte destroyed free expression by burning books, raiding bookstores and destroying publishers' stockpiles. Columbian poet José Pena was found shot to death. It is believed his pro-trade union poems led to his shooting by security forces. Six authors were arrested in 
Paraguay in the late 1970s for government opposition. In 1989, thirty-five journalists were assassinated in Latin America. The most assassinations took place in Peru, Chile and El Salvador.

Besides assassinations in El Salvador, abductions have also taken place. Writer Edgar Mauricio Vallejo appears to have been abducted by the National Police. In the late 1970s, Anastasio Somoza's National Guard in Nicaragua seized books and raided publishing houses. In 1961, an exiled school librarian stated that she and her librarian colleagues were ordered to destroy old history books. That was the year in which private schools were nationalized by the Castro government.

\section{Examples of Global Censorship From the 1950s Through the 1980s: Middle East}

In Iran, several writers have been executed. Some of them were given quick trials while others did not have the luxury of a legal proceeding. Prodigious numbers of authors have been officially prohibited from publishing in Iran. As of 1989, 4,350 authors have been officially blacklisted in Iran. The "Ministry of Culture and Information Act" was ratified in 1981 in the country of Iraq. Under this act, "the Ministry has the mission to supervise all media functions and activities and to exercise cultural supervision over all public and private libraries...." As of 1988, the Israeli military government had banned about 1,600 titles in the West Bank. Dr. Khaldoun al-Naqib, who was the Dean of the Faculty of Arts at Kuwait University, was arrested and fired from his post as Dean for writing the book Society and the State in the Gulf and the Arabian Peninsula.

\section{USA Patriot Act}

For American libraries, the most troubling section of the Patriot Act is Section 215. Section 215 allows the FBI to seek a search warrant to obtain business records from Internet providers, airlines, grocery stores, libraries, bookstores - practically any place. The standard to obtain a search warrant under the Patriot Act is extremely low. All the FBI needs to do is to show that the records they seek are related to an ongoing terrorism investigation.

When discussing search warrants in the United States the first place to look is the Fourth Amendment. It states:

The right of the people to be secure in their persons, houses, papers and effects, against unreasonable searches and seizures, shall not be violated, and no warrants shall issue, but upon probable cause, supported by Oath or affirmation, and particularly describing the place to be searched, and the person or things to be seized.

The Fourth Amendment clearly states that a warrant requires probable cause. "Probable cause" is defined as "A reasonable ground for belief in the existence of facts warranting the proceedings complained of." The Fourth Amendment details that the pursuing agent must "particularly" describe the place, person or things sought to be recovered. This language was put 
into an amendment in reaction to the colonial British governments' "general warrants" which were vague and many times invaded the privacy of the colonists. The Patriot Act arguably returns the United States to the days of British occupation in regard to "general warrants". No longer does an agent need probable cause or any sort of description of "the things to be seized." The federal government can in effect conduct record searches that are illegal under almost every states' law. All that is needed is the government statement that the materials are sought to "protect against international terrorism or clandestine intelligence activities." The court that issues the warrant meets in secret. The warrant itself does not mention the nature of the investigation. Section 215 is extremely broad in how it can be used to compel records of people who are not even suspected of criminal or terrorist activity. Any unsupported assertion apparently will suffice. This can have a dangerously chilling effect on what a person chooses to look at or read in a library. Attorney General Ashcroft had stated that Section 215 of the Patriot Act has not been used as of September 2003. Regardless of whether the Patriot Act is being used or the newly broadened National Security Letters or something else, the number of libraries that have been surveilled since 9/11 has greatly increased. There is a history in the United States that constitutional rights can be altered by the government during times of war. President Bush has claimed there is a "war on terrorism" and a "war in Iraq" but there has not been an official declaration of war. Even if there was an officially declared war, what can be found from library records to further the cause is bewildering.

Another incredibly chilling aspect of Section 215 is the indefinite "gag order" provision which prohibits a person that is served a warrant from disclosing that fact. This enhanced power given to governmental agents sweeps aside constitutional checks and balances. Under the laws of the United States, only the person who is the subject of a search warrant has the authority to challenge a warrant. Since the patron being spied upon does not know of the existence of the search warrant, they cannot challenge the warrant. Librarians, as stated above, have a "gag order" placed upon them but even if they could speak, they are third parties who cannot challenge the warrant. The Patriot Act does allow for tort causes of action against those agents who inappropriately record material of a sensitive nature. Clearly this remedy is too little too late. The private information will have already been made public. Ashcroft's office has tried to calm the public, stating Section 215 "imposed more restrictions to its use than a federal grand jury subpoena for the same records” and contains "explicit safeguards for activities protected." Section 215 orders are actually much less restrictive than a grand jury subpoena. A Section 215 order is immediately executable while a grand jury subpoena can be challenged in court before the information is turned over.

The USA Patriot Act was passed in a patriotic frenzy shortly after 9/11. The Act pushed through Congress and was passed on October 26, 2001, without one mark up in committee or congressional hearing. Democratic Senator Feingold of Wisconsin was the only senator who refused to accede to Senator Leahy (Democrat from Vermont who was the Judiciary Committee Chairman) and Senator Dasches' (Democrat from South Dakota who was the Senate Majority leader) demand that the Democratic senators vote unanimously. Feingold was very concerned with the invasion of personal privacy and in particular Section 215 powers given to the government. Feingold refused to capitulate and attempted to introduce amendments three times to moderate the act. After the final amendment was tabled in a vote of 90 to 7, Arlen Specter, Republican senator from Pennsylvania, stated:

.... when the majority leader says he is concerned about procedure and not about substance, we have not shown 
the deliberate process to uphold constitutionality, but we are putting on the record the disregard for constitutionality and elevating procedure over substance, which is not the way you legislate in a constitutional area where the Supreme Court of the United States balances law enforcement's needs with the incursion on privacy.

In the end, the Senate voted and Feingold was the only nay vote. Now it was up to the House to slow this train. Ironically the person who was willing to put on the brakes was the Judiciary Committee Chairman, F. James Sensenbrenner, Republican from Wisconsin. Sensenbrenner was highly criticized by the press, particularly the conservative press, for his action. Two weeks later with the bill marked up, the House Judiciary Committee passed the bill 36-0. Ashcroft and his staff were persistent as stated by Laura Murphy, ACLU Washington Office head in the Washington Post, "The revised bill cleared the House Judiciary Committee by a vote of 32 to zero. Then in the middle of the night - it was reprinted at 3:30 A.M. - the bill was rewritten again to get all the troublesome stuff back in. When the members voted the following day, hardly anyone except a few staffers had actually seen the bill they were voting on.”

The Patriot Act became law on October 26, 2001. Now library records can be obtained without a court ordered subpoena, which can be challenged in court. There has been public outcry over the USA Patriot Act since its passing. The American Library Association has been very vocal. Judith Krug, the head of the ALA's IFC, has stated that the Patriot Act strikes at two core principles of libraries: intellectual freedom and privacy. The ALA, along with several other library associations including the American Association of Law Libraries, has unveiled a petition to Congress to amend Section 215 of the Patriot Act. The American Library Association has advocated libraries using a chain of decision making or a specific librarian appointed to deal with privacy issues. Another recommendation the ALA has advanced is legal counsel being present before complying with a warrant from government officials. The most practiced ALA recommendation among libraries is keeping patron records to a minimum so the FBI cannot garner much information in a surveillance effort.

The American Library Association and other library organizations got under the skin of previous United States Attorney General, John Ashcroft. In September of 2003, Ashcroft accused librarians of being "hysterical." He also stated librarians had been "duped" by liberals. In addition, he stated, "Section 215 has not been used. Period. Zero times." The Attorney General may be telling the truth when he refers to the non-use of Section 215, but he is being selective as to what he is choosing to declassify according to the Washington Post. Just four weeks after Ashcroft made this declaration, records obtained by the ACLU through the Freedom of Information Act show the FBI had asked the Justice Department to ask the Foreign Intelligence Surveillance Act (FISA) court to approve a search under Section 215.

This heated reaction by the United States Attorney General to librarians and the claimed non-use of Section 215 has understandably raised interest across the United States. Nancy Murray, director of the ACLU's Bill of Rights Education Project in Massachusetts, says Ashcroft's denial of using Section 215 is a lie. On the Public Broadcasting System program, 
“Now with Bill Moyers”, Bob Barr, former Republican congressman from Georgia, stated in response to being questioned about Ashcroft not using Section 215, "there are a number of different ways under the Patriot Act that the government can get the same information .... One has to presume that if the government has sought and has been given a particular power .... I think we have to legitimately and realistically presume they are using these powers." Barr went on to stress everything is done in secret so you never know what is actually being done. If Section 215 is not being used why is Ashcroft insistent that it not be a victim of the sunset provisions? To state that a part of the Patriot Act is never used but then to insist it be reinstated is confusing.

Another feature of the Patriot Act that is of concern to libraries is the expansion of circumstances in which a pen register warrant is available. The section of the Patriot Act allowing this, Section 216, largely predates September $11^{\text {th }}$, 2001. In fact, the original legislation predating 9/11 was concerned with procuring non-adversarial information and was not tied to terrorism at all.

A pen register type of trap and trace device is one only in theory these days. Originally, it was devised to be placed on a telephone line which allowed the recording of the numbers being called or called from one certain telephone. As it was only able to record the telephone number, it did not have the capacity to capture any other information, such as who actually called or any of the content of the conversation. The information captured by the pen register (telephone numbers) was not entitled to constitutional protection. Thus, the standard needed to obtain a pen register under the 1986 legislation authorizing registers was very low ("relevant to an ongoing investigation"). The courts have routinely rubberstamped the requests. Because of the limited nature of a pen register, there was little controversy.

The Patriot Act expands the use of "pen register" warrants to allow them to be used to monitor computer networking information, specifically, the addressing and routing of a computer that is accessing the Internet. This is disconcerting to libraries for two reasons. The first reason is that when a pen register order was previously authorized for a phone line, it was physically placed on that line by the phone company. The phone company was in charge of maintaining the line and thus there was no question about the line being accessed. The phone company had the technical skills and equipment necessary to accomplish this. Conversely, in order to give the government access to computer networks, Section 216 grants the government authority to require other organizations to do this maintenance and thus give libraries a new unwanted responsibility. In addition, a trap and trace on a computer in a public library is presumably going to be directed at one particular person, rather than a single computer. This obviously creates many technical difficulties for the library in attempting to track one person considering the open nature of a public library's computer availability and the fact libraries cannot disclose communications being monitored.

The second problem is the potential information that can be gathered now under the Patriot Act far exceeds what a telephone pen register could previously gather. The information value of a record of all the web pages that a patron has viewed far exceeds that of a simple list of phone numbers that have been dialed or received from a particular phone line. In addition, email and IP addresses can be monitored. There are serious First Amendment and privacy concerns 
with allowing a trap and trace warrant on a computer. Agents and officers seeking warrants need only affirm the information sought is relevant to a criminal investigation. It is not limited to terrorism or foreign intelligence concerns. Any library concerned about privacy is naturally going to have concerns about being required to comply with this sort of order on a rubberstamp without the ability to question its authority.

In essence what Section 216 did from a librarian's perspective is extend the reach of a pen register order. Now, without any Fourth Amendment protections, a patron's use of a computer terminal can be monitored. The government is capable of watching what patrons are typing and reading online, while they are reading it. An example of what is taking place was reported in New Mexico. A former public defender was using a library computer at a Santa Fe academic library when he was arrested by federal agents and interrogated for five hours for stating in a chat room that President Bush was out of control.

If a person took Ashcroft at his word that Section 215 has not been used, there is still much to be suspicious about. The FBI can obtain similar information through a mechanism called a National Security Letter (NSL). NSLs were introduced in 1986 and traditionally were used in non-adversarial situations where the information provider wanted to cooperate with the request but needed a legal framework in which to do so. The NSL's reach was broadened by the Patriot Act in 2001 and they are seeing increasing adversarial use. NSLs can be used under the Electronic Communications Privacy Act, the Right to Financial Privacy Act and the Fair Credit Reporting Act to gain information about "subscriber information and toll billing records information, or electronic communication transactional records." Interestingly enough, no definition of electronic communication transactional records is found in the statute and thus the FBI has wide latitude in what it considers an appropriate target for information available under an NSL. In any case it is almost certainly broad enough to allow the FBI to identify an otherwise anonymous Internet user and reconstruct a detailed history of the user's activity online.

The organizations required to comply with NSLs occupy a similarly broad range. The Electronic Communications Privacy Act requires any Electronic Communication Service Provider (ECSP) to comply with an NSL. An ECSP is defined as "any service which provides users thereof the ability to send or receive wire or electronic communications." Clearly, any library that provides public Internet access is such a provider but it may also include a library that simply maintains a website that allows some sort of user access.

Originally the issuance of an NSL required a showing of individualized suspicion in which the government had to show the target was a foreign power or the agent of a foreign power. However, the Patriot Act lowered this standard so that it now only requires that the government state that the materials are sought to "protect against international terrorism or clandestine intelligence activities." There is no requirement that the FBI state the grounds for their request. This has the effect of broadening the reach of NSLs from only suspected terrorists or spies to potentially anyone. In addition a "gag order" provision was also added that prevents the service provider from disclosing the receipt or compliance with an NSL. This gag order does not expire, even after the investigation is completed. The NSL has thus become a de-facto subpoena for the FBI. A subpoena with no judicial oversight and one that denies the subject of 
the investigation any notification during or after the investigation that his/her records have been accessed by the government.

As Foerstel states, “If NSL's are being used to routinely acquire library records, with an accompanying gag order, it is misleading to hide the fact under the claim of "zero use of Section 215.” This is especially true given statements by the government itself in regard to library records and Section 215; that "(i)f the FBI were authorized to obtain the information the more appropriate tool for requesting electronic communication transaction records would be the National Security Letter (NSL).” The only honest thing for Ashcroft to have done would have been for him to order the release of full aggregate data on the use of NSLs, Section 215, Section 216 and any other tool that has intruded on library confidentiality. Congress had interest in amending the Patriot Act. Some of the bills proposed directly affected Section 215 and libraries. Alberto Gonzales, who worked as an attorney for President Bush when he was governor of Texas, was appointed the new attorney general at the beginning of Bush's second term. Gonzalez is pushing hard for the United States Congress to renew the Patriot Act provisions that would expire December 31, 2005.

\section{Legislation Around the World}

The United Kingdom soon passed the Anti-Terrorism Act in December, 2001, after the quick passage of the Patriot Act. The Anti-Terrorism Act, however, does not have same chilling effect the Patriot Act has on intellectual freedom. The Anti-Terrorism Act has a very important "special procedure material" exception. Under this law a judge would have to find the confidential information sought would add substantial value to the investigation. There would also have to be a showing that there is no other way of gaining access to the private material. In addition, the search would need to be in the public interest and outweigh any harmful effects to confidential and fiduciary relationships.

Australia has been a leader in legislation adoption regarding national security since September 2001. In June of 2003, the “Australian Security Intelligence Organization Legislation Amendment” was passed. It allows authorities to detain citizens eighteen years or older up to seven days if it is believed the citizen may have information regarding a terrorism threat. If directly involved with terrorism or suspected thereof, the citizen may be detained if only sixteen. Interrogation can continue for three eight-hour periods. There are no limits on warrants and they may be applied successively. Canada passed its anti-terrorism law in December of 2001. It does not require warrants or investigative hearings for preventative arrests. A back tracking Solicitor General issued a report stating that no arrests without warrants or investigative hearings have transpired since the enactment of the law. Germany passed legislation making it easier for authorities to intercept online communications. Kenya passed the "Suppression of Terrorism Bill" in June of 2003, which allows any police officer that is above the rank of inspector to detain a terrorist suspect for up to 36 hours without access to a lawyer. The Philippine's AntiTerrorism Action Council, made up of eight counsel members and the Central Bank governor, can freeze bank accounts of suspects and authorize the interception of online communication. The Sudan has set up a special branch to investigate and prosecute suspects of terror; in particular, "religious extremist and armed bandits." Cuba's law on terrorism allows authorities 
to "hack" into a suspect's, hardware and software configurations. The European Union, United Nations, NATO and Council of Europe have also responded in various ways to the threats of terrorism.

\section{Conclusion}

Hopefully this paper has made one think of intellectual freedom and libraries' important role in its achievement. Robert Fisk, decorated British foreign correspondent for the London Times and UK/Independent, has been based in the Middle East for over twenty five years. He brings us full circle on this topic. As Baghdad was burning, Fisk caught sight of the Koranic Library in flames. This is the National Library and Archives in Iraq, holding priceless treasures of Ottoman historical documents. He ran to the US Marines' Civil Affairs Bureau. He shouted to the Marines that the biblical library was burning. "I gave the map location, the precise name in Arabic and English. I said the smoke could be seen from three miles away and it would take only five minutes to drive there. Half an hour later, there wasn't an American at the scene and the flames were shooting 200 feet into the air.” The day before Fisk had reported that the troops had prevented fire and looting at two locations. One location was the Ministry of Oil, which held information about oil fields, both in operation and in reserve. The second location being saved was the Ministry of Interior, holding Iraq's intelligence. All the other museums, historical sites, etc. were left to ruin.

\section{References}

Agrawal, D.R. (2001). Should certain books be banned? Center for First Amendment Rights, Inc. Retrieved September 23, 2004, from http://www.cfarfreedom.org/2001contest/agrawal.html.

American Library Association. (2003). Intellectual freedom (No.2) [ALA Action Pamphlet]. Chicago: American Library Association.

Berninghansen, D.K. (1948, July). Annual report of the committee on intellectual freedom. American Library Association Bulletin, 286-87.

Berry, J.N. (1989, Dec.). Little shop of subversion. Library Journal, 6.

Black's law dictionary (5 ${ }^{\text {th }}$ ed.). (1983). St. Paul, Minn: West Publishing.

Boyle, K. (Ed.). (1988). Article 19: Information freedom and censorship. World Report (pp. 34, 73, 143-166, 185210, 227-239). Essex, England: Longman Group.

Brown, J.E. (2003). Letter to F. James Sensenbrenner, Jr., Chairman of the Judiciary Committee. Location: House of Representatives.

Bryant, D.J. (2002). Letter to F. James Sensenbrenner Jr., Chairman of the Judiciary Committee. Location: House of Representatives.

Byrne, A. (1999, November). Libraries and Democracy. Paper presented at the Seminar on Libraries and Democracy, Stockholm.

Center for Democracy and Technology. (2000). CDT's analysis of S.2092: Amending the pen register and trap and trace statute in response to recent internet denial of service attacks and to establish meaningful privacy protections. Retrieved September 23, 2004, from www.cdt.org/security/000404amending.shtml 
Chadwell, F. (2002). Intellectual freedom, an evolving and enduring value of librarianship. Oregon Library Association Quarterly, 8 (1). Retrieved September 20, 2004, from www.olaweb.org/quarterly/quar8$1 /$ chad.stml.

City of West Covina v. Perkins, 525 U.S. 234, 240 (1999).

Congressional Record - Senate, October 11, 2001, §10578-10579.

Crawford, J. (2002). The community library in Scottish history. IFLA Journal 28(5/6), 246.

De Baets, A. (2002). Censorship of historical thought: A world guide, 1945-2000. (p.142). Westport, Connecticut: Greenwood Press.

Doe v. Ashcroft, Amicus Brief Curiae, Electronic Frontier Foundation, 2004 WL 1065536 (2004).

Eggen, D. (2003, September 18). Ashcroft: Patriot Act Provision Unused. Washington Post, A13.

Executive Order 9835, (1947).

Fisk, R. (2003, April 14). Americans defend two untouchable ministries from the hordes of looters. Independent/UK. Retrieved April 9, 2005, from http://www.independent.co.uk/world/middle_east/storyjsp?story=396997.

Fisk, R. (2003, April 15). Library books, letters and priceless documents are set ablaze in final chapter of the sacking of Baghdad. Independent/UK. Retrieved April 9, 2005, from www.ccmep.org/2003_articles/Iraq/041503_library_books.htm.

Foerstel, H. (2004). Refuge of a scoundrel. Westport, CT: Libraries Unlimited.

Geller, E. (1984). Forbidden books in american public libraries, 1876-1939. (pp. 5, 127-159, 175). Westport, CT: Greenwood Press.

Goldstein, A. (2004, June 18). Patriot Act provision involved, memo says. Washington Post, A11.

Grammer, G. (2003, February 16). Paranoia blamed for St. John’s incident. Santa Fe New Mexican, B1.

Green, J. (1990). The encyclopedia of censorship. (pp. 31, 154). New York: Facts on File.

Hamilton, S. (2002). Internet accessible information and censorship, intellectual freedom and libraries - a global overview. IFLA Journal, 28(4), 195.

Heller, N.J. (2004, May 17). Libraries juggle privacy issues. Harvard Crimson, Retrieved September 20, 2004, from www.thecrimson.com/articles.aspx?ref=502603.

How libraries are involved in issues of public safety and intellectual freedom (2003, July 2). Talk of the Nation, [Radio Broadcast Series]. Philadelphia: National Public Radio.

IFLA/FAIFE (Ed.) (2001). Libraries and intellectual freedom. IFLA/FAIFE World Report. (p. 115). Denmark: IFLA/FAIFE.

Ingelhart, L.E. (1998). Press and speech freedoms in the world from antiquity until 1998: A chronology. Westport, CT: Greenwood Press. 
Ivey, L.M. (2002). Ready, aim, fire? The President's executive order authorizing detention, treatment, and trial of certain non-citizens in the war against terrorism is a powerful weapon, but should it be upheld?

Cumberland Law Review, 33(1), 107.

Japanese denounce actions of the Nazis. (1933, May 14). New York Times, 3.

Josey, E.J., \& Shockley, A.A. (Eds.). (1977) Handbook of Black Librarianship. (pp.15-24). Littleton, CO: Libraries Unlimited.

Laporte, A. (2000, November). Origins and evolution of the Windsor Public Library System 1894-1967. Paper presented at Windsor, Ontario, Canada.

Library community statement on proposed anti-terrorism measures. (2001, October 2). American Library

Association. Retrieved September 20, 2004, from

www.ala.org/ala/washoff/WOissues/civilliberties/theusapatriotact/terriorism.pdf.

Lujan v. Defenders of Wildlife, 504 U.S. 555, 555-56 (1992). Makar, R. (1996, November). New voices for women in the Middle East. Paper presented at the Middle East Libraries Association Annual Meeting, Providence, Rhode Island.

Mart, S.N. (2004). Protecting the lady from Toledo: Post-USA Patriot Act electronic surveillance at the library. Law Library Journal, 96(3), 452-456.

Martin, K. (2003). The USA PATRIOT Act’s application to library patron records. Journal of Legislation, 29(2), 283, 289.

McCaffrey, S. (2004, May 24). New laws to combat terrorism are working their way through Congress. Knight Ridder Washington Bureau.

Moore, E.T. (Ed.). (1964). Issues of freedom in american libraries. (pp. 7, 73). Chicago: American Library Association.

Now With Bill Mayers, (2003, November 16). [Television Series]. Alexandria, VA: Public Broadcasting Service Television..

Peattie, N. (1987). Intellectual freedom activism in the sixties: The defense of a professional standard. In Activism in American Librarianship, 1962-1973. (p. 50). Westport, CT: Greenwood Press.

Peleg, I. (1993). Patterns of censorship around the world. Boulder, CO: Westview Press.

A policy on confidentiality of library records. (1988). ALA handbook of organization 1988/89. Chicago: American Library Association.

Poynder, R. (2004, January). Fiddling while Rome burns? Information Today, 21(1).

Raspberry, W. (2003, July 21). Homeland security sales pitch. Washington Post, A21.

Readers group seeks Patriot Act amendment (2004, February 27). Associated Press. Retrieved September 20, 2004, from www.cnn.com/2004/US/west/02/27/books.patriot.act.ap/

Robbins, L.S. (1996). Censorship and the American library: the American Library Association's response to threats to intellectual freedom, 1939-1969. (pp. 9-38, 67, 69-104, 117-139). Westport, CT: Greenwood Press.

Rojers, R.A. (1984). The library in society. (p. 20). Littleton, CO: Libraries Unlimited. 
Salmon, L.M. (1923). The newspaper and authority. Oxford: Oxford University Press.

Samek, T. (1996). The Library Bill of Rights in the 1960s. One profession, one ethic. Library Trends, 54. Retrieved September 20, 2004, from http://infotrac.galegroup.com/itw/infomark/208/605/49834482W1.

Stern, G. (1997). The burning of the books in Nazi Germany, 1933: The American response. Simon Wiesenthal Center Annual 2. Retrieved April 10, 2005, from http://motc.wiesenthal.com/resources/books/annual2/chap05.html.

Stielow, F. (1993, Sep.). The FBI and library spying: A World War II precedent. American Libraries, 709-711.

Stielow, F. (1987). The war and librarianship: A study in political activism. In Activism in American librarianship, 1962-1973. (pp. 31,39). Westport, CT: Greenwood Press.

State of the Union Address, January 20, 2004.

Tawa, R. (2003, May 28). Pro-Constitution, Anti-Patriot. Los Angeles Times, E1.

Taylor, T. (1969). Two studies in Constitutional interpretation: Search, seizure and surveillance and fair trial and free presses. (pp. 24-50). Columbus, OH: Ohio State University Press.

United States Code, Title 18, Section 2709.

United States Code, Title 18, Section 1462.

United States Constitution, Amendment IV.

U.S. Internet Service Provider Assoication (2003). Electronic evidence compliance - A guide for Internet service providers. Berkeley Tech Law Journal, 18(4), 974.

USA PATRIOT ACT of 2001 §215, United States Code, Title 50, Sections 1861-1862.

United States v. Rumely, 345 U.S. 41, 57-58 (Douglas, J. concurring).

Wiegand, W.A. (1989). An active instrument for propaganda: The American public library during World War I. (pp. 1-6). Westport, CT: Greenwood Press.

Wiegand, W.A. (1986). The politics of an emerging profession: The American Library Association, 1876-1917. Westport, CT: Greenwood Press.

Young, A.P. (1981). Books for Sammies: The American Library Association and World War I. Pittsburg: Beta Phi Mu. 


\section{Author Note}

Joseph A. Custer is the Associate Director of the University of Kansas School of Wheat Law Library. He is also a Lecturer at the School of Law and the Collection Development Librarian at the University of Kansas School of Wheat Law Library. He received a M.A. degree in Library and Information Science from the University of Missouri and a J.D. from the University of Arkansas. Before that, he was the Director of Information Services at the Law Firm of Gage and Tucker in Kansas City, Missouri. He has taught Introduction to Legal Research and Writing. He currently teaches Advanced Legal Research and other Advanced Topical classes in Legal Research. In addition he teaches classes in Legal Information Management. Mr. Custer is the author and editor of the second and third editions to the Kansas Legal Research and Reference Guide and has written several articles on the subjects of legal research and legal information. Mr. Custer is a member of the Kansas Bar Association, Missouri Bar Association, American Bar Association, American Association of Law Librarians, American Library Association and the Mid-America Association of Law Libraries. 
Reproduced with permission of the copyright owner. Further reproduction prohibited without permission. 